\title{
STRUCTURAL EQUATION MODELLING FOR ESTABLISHING EMPIRICAL RELATIONSHIP BETWEEN ORGANISATIONAL INNOVATIVENESS AND SUSTAINABILITY OF CONSTRUCTION FIRMS IN NIGERIA
}

\author{
Monday OTALI' ${ }^{1}$, Emmanuel ACHUENU ${ }^{2}$ and Godwin IDORO ${ }^{3}$ \\ ${ }^{1}$ University of Uyo, Uyo, Nigeria \\ ${ }^{2}$ University of Jos, Jos, Nigeria \\ ${ }^{3}$ University of Lagos, Lagos, Nigeria
}

Corresponding author's e-mail: otalimonday@yahoo.com

\begin{abstract}
The quest to implement innovative practices that will lead to a high level of sustainability at the firm level within the construction sector cannot be overemphasised. The aim of this study is to establish the empirical relationship between organisational innovativeness and sustainability of construction firms using a structural equation modelling approach. The study has adopted a survey approach and 1179 copies of structured questionnaire have been administered to construction firm representatives. A total of valid 980 copies of questionnaire have been received giving a response rate of $83.2 \%$. Data collected have been analysed using descriptive statistics and structural equation modelling. The correlation coefficient $(\beta=0.81)$ shows that organisational innovativeness positively influences the sustainability of construction firms. The study reveals that $66.1 \%$ of the variability in the overall sustainability of construction firms operating in the Niger Delta region of Nigeria is accounted for by the implementation of innovative practices by the construction firms. It is concluded that $67.1 \%, 83.8 \%$ and $45.7 \%$ of the variability in the construction firm's social, environmental and economic sustainability, respectively, are explained by the implementation level of innovative practices by the top management teams of the firms. In line with the findings, this study concludes that efficient implementation of innovative practices at the firm level has a significant and positive influence on the overall sustainability of construction firms.
\end{abstract}

Keywords: Empirical relationship; Nigeria; Organisational innovativeness; Structural equation modelling; Sustainability of construction firms.

\section{INTRODUCTION}

The quest to implement innovative practices that will lead to a high level of sustainability at the firm level within the construction sector cannot be overemphasised. Having a good knowledge of the dimensionality of firm sustainability enables the construction firms to make better decisions about which indicators to include or leave out, and the potential consequences of these choices. Firm performance measurement is of great importance in effective management of the firms and in the enhancement of the processes. Love and Roper (2015) posited that many corporate organisations introduced innovation into their business operations in order to increase their productivity, competitiveness, market share 
which would lead to higher profit. Organisations that have greater capacity to implement innovative practices respond to environmental challenges faster and better than the organisations that are not innovative (Rukundo, 2017).

Innovation is defined as the introduction of new products, services, or processes to the external market or the introduction of new devices, systems, programs, or practices in one or more internal units (Walker et al., 2011). Most studies carried out on innovation emphasised technology-based products and process innovations (Evangelista and Vezzani, 2010). Product innovations are usually defined as new products or services introduced to meet an external user need, while process innovations are defined as new elements introduced into a firm's production or service operation to produce a product or render a service (Damanpour, 2010; Schilling, 2013, Yusof et al., 2014). There are some other dimensions of innovation, which include paradigm innovation, technical/technological innovation, information technology innovation, and administrative innovation (Moohammad et al., 2014).

Singh, Murty, Gupta and Dikshit (2009) state that there is an inadequate effort to measure firms' commitment to sustainability with an integral approach that encompasses environmental, economic and social aspects. Hence, there is a need to evaluate the level of corporate commitment to the three pillars of sustainability in Niger Delta, Nigeria. Many studies were carried out to determine key performance indicators (KPIs) but most of them were project specific. Existing research that evaluated the sustainability of construction firms is limited in the literature (Ali, AlSulaihi and Al-Gahtani, 2013). Combs, Crook and Shook (2005) stated that firm sustainability suffers from the lack of consensus and proper consideration of its dimensionality. Financial measures are often used alone regardless of the growing importance of other social and environmental aspects. Many studies represented firm sustainability as unidimensional despite the acknowledgement of its multidimensionality (Glick, Washburn \& Miller, 2005). Shen et al. (2010) state that a greater emphasis is placed on economic and social sustainability. In contrast, Tam (2008) and Lilja (2009) maintain that in the construction industry, sustainability is generally interpreted as environment oriented. In view of this consideration, the present study considers the environmental, social and economic sustainability of the construction firms operating in the Niger Delta region of Nigeria.

Hassan, Shaukat, Nawaz and Naz (2013) assessed the influence of innovation on firm Performance in the Pakistan's manufacturing sector, and the study revealed that there was a positive influence of innovation types on firm performance. Karabulut (2015) evaluated the influence of innovation on performance of manufacturing firms in Turkey and the result showed that product, process and organisational innovation had a direct and positive influence on organisational performance. Bowen et al. (2010) revealed a positive relationship between innovativeness and firm performance. Mafini (2015) also predicted organisational performance through innovation, quality and inter-organisational systems in the public sector. The findings of the study indicated that there was a strong positive relationship between innovation and organisational performance. Chan and Liu (2012) showed that organisational innovativeness influenced productivity, profitability and competitiveness, sustainability adoption in an organisation. 
Furthermore, Gauthier and Wooldridge (2012) also found that innovation addressed sustainability issues in the construction sector. However, there are limited studies on the relationship between organisational innovativeness and sustainability of construction firms in Nigeria in general and Niger Delta in particular. Hence, the aim of this study is to establish the empirical relationship between organisational innovativeness and sustainability of construction firms using a structural equation modelling approach.

\section{RESEARCH METHODOLOGY}

Structured questionnaire was used as a research instrument for data collection in this study. The questionnaire consists of three parts. The first part comprises the educational qualification, work experience and professional affiliations of the firm representatives. The second part comprises the constructs and dimensions used to assess the level of implementation of innovation in the construction firms, while the third part contains the construct and dimensions used to assess the firm sustainability. The 1179 copies of questionnaire were administered to the construction representatives comprising project managers, architects, builders and civil engineers working at the construction firms operating in the Niger Delta region of Nigeria. The result of descriptive statistics showed that the construction professionals (project managers, architects, builders, civil engineers) possessed the minimum qualification of Higher National Diploma (HND).

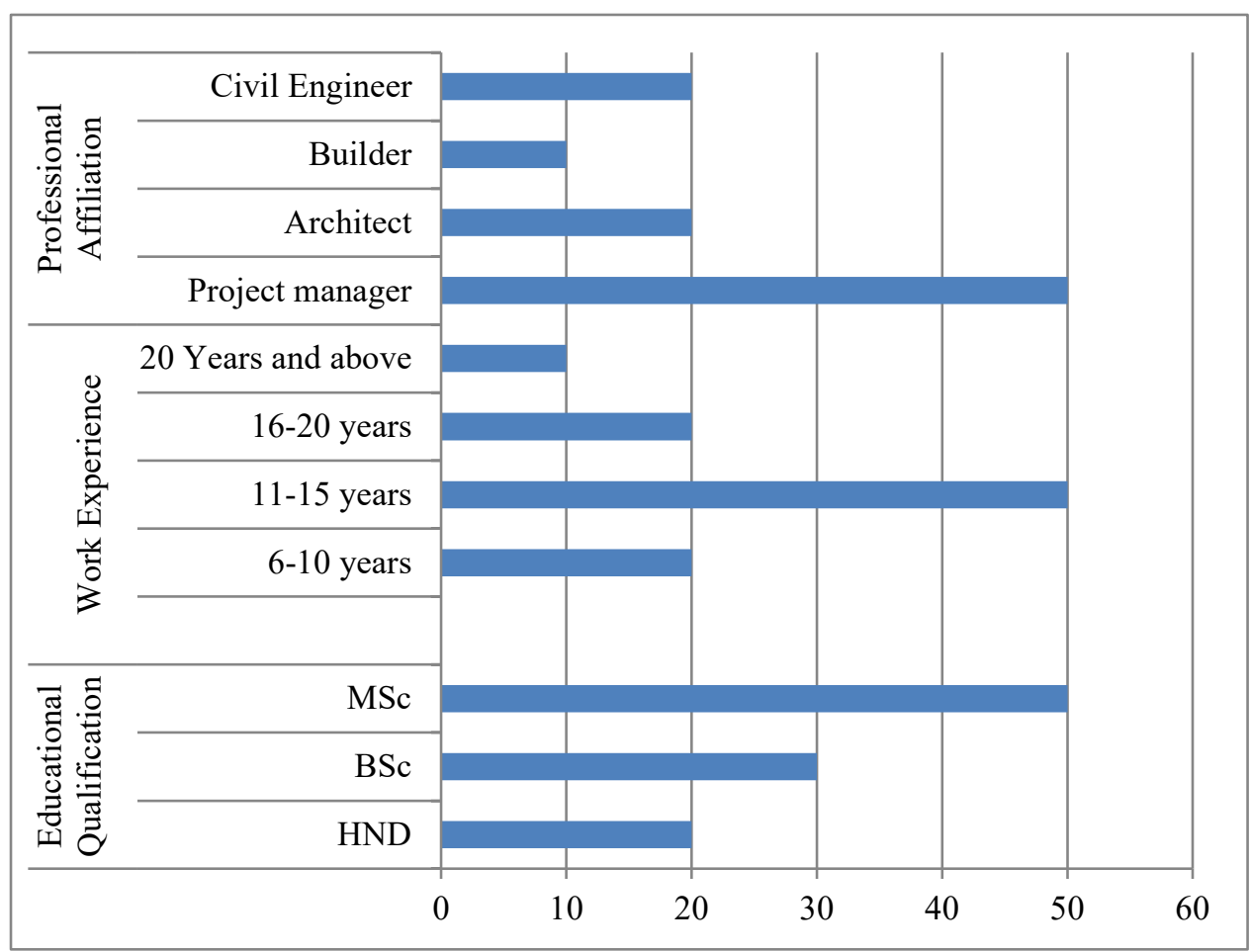

Fig. 1. Educational qualification, work experience and professional affiliation of the firm representatives (developed by the authors). 
Figure 1 shows that $20 \%, 30 \%$, and $50 \%$ of the firm representatives possessed HND, BSc and MSc, respectively. In the same way, $50 \%, 20 \%, 10 \%$ and $20 \%$ of the firm representatives are project managers, architects, builders and civil engineers, respectively. The work experience of the firm representatives ranged between the intervals of 5-10, 11-15, 16-20 and above 20 years. Furthermore, 50 $\%$ of the firm representatives had work experience above 10 years. The educational qualification and work experience of the respondents were adequate and their responses could be relied on. A five-point (1-5) Likert scale was used for data collection. Scale 1 implies a very low level of implementation of organisational innovativeness/very low level of firm sustainability, while scale 5 implies a very high level of implementation of organisational innovativeness/very high level of firm sustainability (Kazaz et al., 2008; Santos \& Brito, 2012). Structural equation modelling (SEM) was used to establish the empirical relationship between organisational innovativeness and sustainability of construction firms.

\section{RESULT ANALYSIS AND DISCUSSION}

This section contains the descriptive results of the questionnaire distributed to the firms as well as the response rate. It also provides the results of the structural equation model establishing the empirical relationship between organisational innovativeness and the sustainability of construction firms.

\subsection{Questionnaire Administration and Response Rate}

The structured questionnaire was used as a research tool for data collection in this study. Figure 2 shows the number of questionnaires administered to construction companies through their representatives, the number of questionnaires returned, and the response rate. Figure 2 indicates that the response rate ranged between $76.10 \%$ and $94.7 \%$. According to Fig. 2, construction firms operating in Delta state recorded the highest response rate $(94.7 \%)$, while the construction firms operating in Abia state had the least response rate (76.10\%).

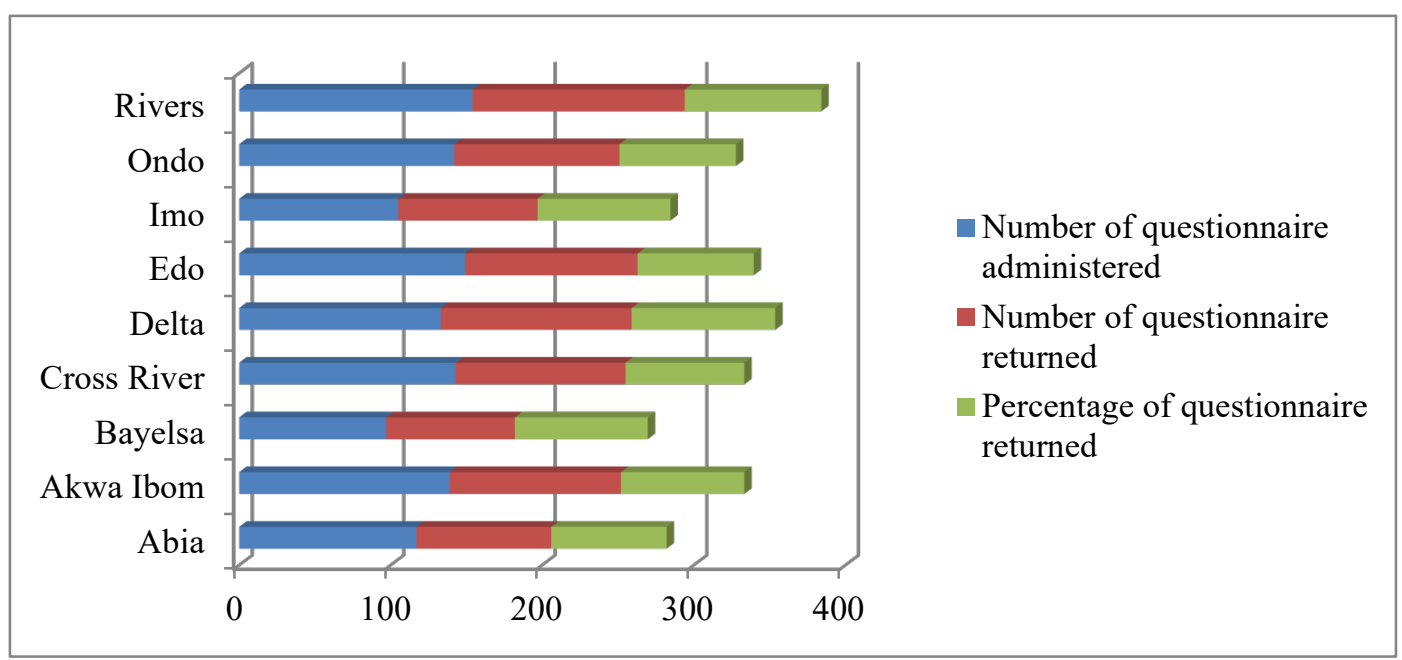

Fig. 2. Questionnaire administration and response rate (developed by the authors). 
The study shows that the overall response rate is $83.2 \%$. In agreement with Groves (2006), the response rate is considered very good and adequate in the study.

\subsection{Structural Equation Modelling (SEM) for Establishing the Empirical Relationship between Organisational Innovativeness and Sustainability of Construction Firms}

Structural equation modelling was used to establish the empirical relationship between organisational innovativeness and the sustainability of construction firms. These processes include model estimation, verification and validation of the final model.

\subsubsection{Model Estimation}

Maximum likelihood estimate (MLE) was applied to determine the unique contrast between the constructs and dimensions in the study. The Promax rotation method was used to show the principal dimensions that formed contrast patterns between the variables. Furthermore, the promax rotation method was used due to the large data involved and it also accounted for the correlation between variables. The result showed that KMO was 0.744 , and $p$-value $=0.001$ at 0.05 level of significance, which confirmed the appropriateness and adequacy for conducting a factor analysis for the data set. The computed value of the KMO was greater than the bench mark of 0.5 for KMO and Bartlett's test $<0.05$. This confirmed the appropriateness and adequacy for conducting a factor analysis for the data set.

The study was not about grouping data because the breakdown of organisational innovativeness and sustainability of construction firms into constructs and dimensions from the literature was carried out at the preliminary stage. Principal component analysis (PCA) was used in this study to reduce the variables and find the smallest components that explained most of the variations in the data set. The result of the rotated matrix of components indicated that no component had less than three variables. The result also indicated that the correlation coefficient $(R)$ was greater than 0.3 for each variable. It also satisfied the condition stated in the literature by Tabachnick and Fidell (2007), who posited that the correlation coefficient $(R)$ had to be 0.30 or greater, because anything below suggested a very weak relationship between the variables.

\subsubsection{Verification and Validation of the Final Model}

The final model was validated using the model fit indices. The results in Table 1 show that the model fit indices of the final model satisfied the bench marks stipulated in the literature. The results show that the estimates were within the expected limits. The values of chi-square / degree of freedom, goodness of fit, root mean square, error of approximation, comparative fit index, Tucker Lewis index, normed fit index, incremental fit index and relative index were 1.9677, 0.9547, $0.0748,0.9579,0.9564,0.9632,0.9523$ and 0.9657 , respectively. The values of these model fit indices showed a satisfactory model fit. This study agrees with other studies in the literature that used many model fit indices to determine the overall fitness of the model (Schumacker and Lomax, 2004; Zulu, 2007; Hair et al., 2010; and Byrne, 2016). 
Table 1. Model Fit Indices (developed by the authors)

\begin{tabular}{|l|l|l|l|l|}
\hline Model Fit Indices & Recommended & Source(s) & $\begin{array}{l}\text { Final } \\
\text { Model }\end{array}$ & Remark \\
\hline $\begin{array}{l}\mathrm{X}^{2} / \text { Degree of } \\
\text { freedom }\end{array}$ & $<2$ & Byrne, 2016 & 1.9677 & satisfactory \\
\hline $\begin{array}{l}\text { Goodness of Fit } \\
\text { (GFI) }\end{array}$ & $0-1$ & Bagozzi and Yi, 2012 & 0.9547 & satisfactory \\
\hline $\begin{array}{l}\text { Root Mean Square } \\
\text { Error of } \\
\text { Approximation } \\
\text { (RMSEA) }\end{array}$ & $\leq 0.10$ & $\begin{array}{l}\text { Tabachnick and Fidell } \\
(2007)\end{array}$ & 0.0748 & satisfactory \\
\hline $\begin{array}{l}\text { Comparative Fit } \\
\text { Index (CFI) }\end{array}$ & $>0.9$ & Kline, 2004 & 0.9579 & satisfactory \\
\hline $\begin{array}{l}\text { Tucker Lewis Index } \\
\text { (TLI) }\end{array}$ & $\geq 0.90$ & Bagozzi and Yi, 2012 & 0.9564 & satisfactory \\
\hline $\begin{array}{l}\text { Normed Fit Index } \\
\text { (NFI) }\end{array}$ & $0-1$ & Doloi et al., 2011 & 0.9632 & satisfactory \\
\hline $\begin{array}{l}\text { Incremental Fit Index } \\
\text { (IFI) }\end{array}$ & $0-1$ & Molenaar et al., 2000 & 0.9523 & satisfactory \\
\hline $\begin{array}{l}\text { Relative Fit Index } \\
\text { (RFI) }\end{array}$ & $0-1$ & Doloi et al., 2011 & 0.9657 & satisfactory \\
\hline
\end{tabular}

Table 2 shows the estimates of the standardised regression weight, the standard errors (S.E), and the $p$-values. Furthermore, the feasibility of parameter estimates, the appropriateness of standard errors, and the statistical significance of parameter estimates were assessed for the adequacy of the model. The parameters were checked to ensure that the estimates were correct in order to avoid estimates that had the correlation coefficient greater than one (1). The correctness of the estimates implies that each of the estimates has the correct values and sign. The appropriateness of the standard error is also a key parameter for evaluating the adequacy of the model. Table 2 indicates that the values of standard errors are small, which implies a good model fit. Table 2 also shows that all the $p$-values are less than 0.05 level of significance set for the test. It means that the estimates are significant at the confidence level of $95 \%$. These criteria and checks showed that the model fit was good.

Table 2. Standardised Regression Weights, Standard Errors and Level of Significance (developed by the authors)

\begin{tabular}{|l|l|l|l|l|l|}
\hline & & & Estimate & S.E. & $P$-value \\
\hline CFS & $<---$ & OI & 0.813 & & \\
\hline ECP & $<---$ & CFS & 0.676 & & \\
\hline SP & $<---$ & CFS & 0.819 & & \\
\hline EP & $<---$ & CFS & 0.916 & & \\
\hline OIESAD & $<---$ & OI & 0.731 & & \\
\hline OITSAD & $<---$ & OI & 0.579 & & \\
\hline OIKSAD & $<---$ & OI & 0.965 & & \\
\hline OIRSAD & $<---$ & OI & 0.815 & & \\
\hline
\end{tabular}




\begin{tabular}{|l|l|l|l|l|l|}
\hline & & & \multicolumn{1}{|c|}{ Estimate } & S.E. & $P$-value \\
\hline ECP1 & $<---$ & ECP & 0.515 & & \\
\hline ECP2 & $<---$ & ECP & 0.321 & 0.092 & $* * *$ \\
\hline ECP3 & $<---$ & ECP & 0.425 & 0.098 & $* * *$ \\
\hline OIES4AD & $<---$ & OIESAD & 0.559 & & \\
\hline OIES3AD & $<---$ & OIESAD & 0.545 & 0.086 & $* * *$ \\
\hline OIES2AD & $<---$ & OIESAD & 0.836 & 0.105 & $* * *$ \\
\hline OIES1AD & $<---$ & OIESAD & 0.761 & 0.108 & $* * *$ \\
\hline OITS4AD & $<---$ & OITSAD & 0.656 & & \\
\hline OITS3AD & $<---$ & OITSAD & 0.789 & 0.081 & $* * *$ \\
\hline OITS2AD & $<---$ & OITSAD & 0.800 & 0.080 & $* * *$ \\
\hline OITS1AD & $<---$ & OITSAD & 0.834 & 0.082 & $* * *$ \\
\hline OIKS4AD & $<---$ & OIKSAD & 0.492 & & \\
\hline OIKS3AD & $<---$ & OIKSAD & 0.689 & 0.119 & $* * *$ \\
\hline OIKS1AD & $<---$ & OIKSAD & 0.565 & 0.111 & $* * *$ \\
\hline OIRS4AD & $<---$ & OIRSAD & 0.549 & & \\
\hline OIRS3AD & $<---$ & OIRSAD & 0.701 & 0.106 & $* * *$ \\
\hline OIRS2AD & $<---$ & OIRSAD & 0.781 & 0.098 & $* * *$ \\
\hline OIRS1AD & $<---$ & OIRSAD & 0.724 & 0.098 & $* * *$ \\
\hline EP5 & $<---$ & EP & 0.615 & & \\
\hline EP6 & $<---$ & EP & 0.806 & 0.093 & $* * *$ \\
\hline EP7 & $<---$ & EP & 0.899 & 0.089 & $* * *$ \\
\hline EP8 & $<---$ & EP & 0.809 & 0.087 & $* * *$ \\
\hline EP9 & $<---$ & EP & 0.703 & 0.097 & $* * *$ \\
\hline SP2 & $<---$ & SP & 0.667 & & \\
\hline SP3 & $<---$ & SP & 0.729 & 0.066 & $* * *$ \\
\hline SP4 & $<---$ & SP & 0.820 & 0.067 & $* * *$ \\
\hline SP5 & $<---$ & SP & 0.888 & 0.070 & $* * *$ \\
\hline SP6 & $<---$ & SP & 0.869 & 0.071 & $* * *$ \\
\hline SP7 & $<---$ & SP & 0.878 & 0.066 & $* * *$ \\
\hline SP8 & $<---$ & SP & 0.854 & 0.074 & $* * *$ \\
\hline SP9 & $<--$ & SP & 0.886 & 0.079 & $* * *$ \\
\hline & & & & & \\
\hline
\end{tabular}

Table 3 shows the total effect of organisational innovativeness on the sustainability of construction firms. The correlation coefficient of 0.813 indicates that organisational innovativeness has a direct and positive relationship with the sustainability of construction firms. Table 3 also demonstrates the squared multiple correlations of each variable in the model. The squared multiple correlations reveal the proportion of variability in sustainability of construction firms as explained by the level of implementation of innovative practices. Table 3 shows that $66.1 \%$ of the variability in the overall sustainability of construction firms is explained by the level of implementation of innovative practices by the top management of the construction firms. 
Table 3. Standardised Total Effects and Squared Multiple Correlation (developed by the authors)

\begin{tabular}{|c|c|c|c|c|c|c|c|c|c|c|}
\hline & OI & CFS & SP & EP & $\begin{array}{l}\text { OIRS } \\
\mathrm{AD}\end{array}$ & OIKSAD & OITSAD & OIESAD & $\mathrm{ECP}$ & \begin{tabular}{|l|} 
Squared \\
Multiple \\
Correlation \\
\end{tabular} \\
\hline CFS & 0.813 & 0.000 & 0.000 & 0.000 & 0.000 & 0.000 & 0.000 & 0.000 & 0.000 & 0.661 \\
\hline SP & 0.666 & 0.819 & 0.000 & 0.000 & 0.000 & 0.000 & 0.000 & 0.000 & 0.000 & 0.671 \\
\hline EP & 0.744 & 0.916 & 0.000 & 0.000 & 0.000 & 0.000 & 0.000 & 0.000 & 0.000 & 0.838 \\
\hline OIRSAD & 0.815 & 0.000 & 0.000 & 0.000 & 0.000 & 0.000 & 0.000 & 0.000 & 0.000 & 0.665 \\
\hline OIKSAD & 0.965 & 0.000 & 0.000 & 0.000 & 0.000 & 0.000 & 0.000 & 0.000 & 0.000 & 0.931 \\
\hline OITSAD & 0.579 & 0.000 & 0.000 & 0.000 & 0.000 & 0.000 & 0.000 & 0.000 & 0.000 & 0.335 \\
\hline OIESAD & 0.731 & 0.000 & 0.000 & 0.000 & 0.000 & 0.000 & 0.000 & 0.000 & 0.000 & 0.534 \\
\hline ECP & 0.549 & 0.676 & 0.000 & 0.000 & 0.000 & 0.000 & 0.000 & 0.000 & 0.000 & 0.457 \\
\hline SP9 & 0.590 & 0.726 & 0.886 & 0.000 & 0.000 & 0.000 & 0.000 & 0.000 & 0.000 & 0.786 \\
\hline SP8 & 0.568 & 0.699 & 0.854 & 0.000 & 0.000 & 0.000 & 0.000 & 0.000 & 0.000 & 0.729 \\
\hline SP7 & 0.584 & 0.719 & 0.878 & 0.000 & 0.000 & 0.000 & 0.000 & 0.000 & 0.000 & 0.770 \\
\hline SP6 & 0.578 & 0.711 & 0.869 & 0.000 & 0.000 & 0.000 & 0.000 & 0.000 & 0.000 & 0.755 \\
\hline SP5 & 0.591 & 0.727 & 0.888 & 0.000 & 0.000 & 0.000 & 0.000 & 0.000 & 0.000 & 0.788 \\
\hline SP4 & 0.546 & 0.672 & 0.820 & 0.000 & 0.000 & 0.000 & 0.000 & 0.000 & 0.000 & 0.673 \\
\hline SP3 & 0.485 & 0.597 & 0.729 & 0.000 & 0.000 & 0.000 & 0.000 & 0.000 & 0.000 & 0.531 \\
\hline SP2 & 0.444 & 0.546 & 0.667 & 0.000 & 0.000 & 0.000 & 0.000 & 0.000 & 0.000 & 0.445 \\
\hline EP9 & 0.523 & 0.644 & 0.000 & 0.703 & 0.000 & 0.000 & 0.000 & 0.000 & 0.000 & 0.495 \\
\hline EP8 & 0.602 & 0.741 & 0.000 & 0.809 & 0.000 & 0.000 & 0.000 & 0.000 & 0.000 & 0.654 \\
\hline EP7 & 0.669 & 0.823 & 0.000 & 0.899 & 0.000 & 0.000 & 0.000 & 0.000 & 0.000 & 0.807 \\
\hline EP6 & 0.600 & 0.738 & 0.000 & 0.806 & 0.000 & 0.000 & 0.000 & 0.000 & 0.000 & 0.650 \\
\hline EP5 & 0.457 & 0.563 & 0.000 & 0.615 & 0.000 & 0.000 & 0.000 & 0.000 & 0.000 & 0.378 \\
\hline OIRS1AD & 0.590 & 0.000 & 0.000 & 0.000 & 0.724 & 0.000 & 0.000 & 0.000 & 0.000 & 0.524 \\
\hline OIRS2AD & 0.637 & 0.000 & 0.000 & 0.000 & 0.781 & 0.000 & 0.000 & 0.000 & 0.000 & 0.611 \\
\hline OIRS3AD & 0.571 & 0.000 & 0.000 & 0.000 & 0.701 & 0.000 & 0.000 & 0.000 & 0.000 & 0.491 \\
\hline OIRS4AD & 0.448 & 0.000 & 0.000 & 0.000 & 0.549 & 0.000 & 0.000 & 0.000 & 0.000 & 0.301 \\
\hline OIKS1AD & 0.546 & 0.000 & 0.000 & 0.000 & 0.000 & 0.565 & 0.000 & 0.000 & 0.000 & 0.320 \\
\hline OIKS3AD & 0.665 & 0.000 & 0.000 & 0.000 & 0.000 & 0.689 & 0.000 & 0.000 & 0.000 & 0.474 \\
\hline OIKS4AD & 0.475 & 0.000 & 0.000 & 0.000 & 0.000 & 0.492 & 0.000 & 0.000 & 0.000 & 0.242 \\
\hline OITS1AD & 0.482 & 0.000 & 0.000 & 0.000 & 0.000 & 0.000 & 0.834 & 0.000 & 0.000 & 0.695 \\
\hline OITS2AD & 0.463 & 0.000 & 0.000 & 0.000 & 0.000 & 0.000 & 0.800 & 0.000 & 0.000 & 0.640 \\
\hline OITS3AD & 0.457 & 0.000 & 0.000 & 0.000 & 0.000 & 0.000 & 0.789 & 0.000 & 0.000 & 0.623 \\
\hline OITS4AD & 0.380 & 0.000 & 0.000 & 0.000 & 0.000 & 0.000 & 0.656 & 0.000 & 0.000 & 0.431 \\
\hline OIES1AD & 0.557 & 0.000 & 0.000 & 0.000 & 0.000 & 0.000 & 0.000 & 0.761 & 0.000 & 0.580 \\
\hline OIES2AD & 0.611 & 0.000 & 0.000 & 0.000 & 0.000 & 0.000 & 0.000 & 0.836 & 0.000 & 0.699 \\
\hline OIES3AD & 0.398 & 0.000 & 0.000 & 0.000 & 0.000 & 0.000 & 0.000 & 0.545 & 0.000 & 0.297 \\
\hline OIES4AD & 0.409 & 0.000 & 0.000 & 0.000 & 0.000 & 0.000 & 0.000 & 0.559 & 0.000 & 0.313 \\
\hline ECP3 & 0.234 & 0.287 & 0.000 & 0.000 & 0.000 & 0.000 & 0.000 & 0.000 & 0.425 & 0.181 \\
\hline ECP2 & 0.176 & 0.217 & 0.000 & 0.000 & 0.000 & 0.000 & 0.000 & 0.000 & 0.321 & 0.103 \\
\hline ECP1 & 0.283 & 0.348 & 0.000 & 0.000 & 0.000 & 0.000 & 0.000 & 0.000 & 0.515 & 0.266 \\
\hline
\end{tabular}

\subsection{Relationship between Organisational Innovativeness and Sustainability of Construction Firms}

The results in Tables 1-3 indicate a satisfactory model fit because all output values are within acceptable limits. Statistical significance of parameter estimates was assessed and the results revealed that all the $p$-values were less than 0.05 . It means that all the estimates are significant at the confidence level of $95 \%$. The model fit indices showed a satisfactory model fit. The present research is in consonance with studies performed by Schumacker and Lomax (2004), Zulu 
(2007), Hair et al. (2010) and Byrne (2016) that used many model fit indices to determine the overall fitness of the model.

Figure 3 reveals that organisational innovativeness has a direct and positive influence on the sustainability of construction firms in the Niger Delta region of Nigeria $(\beta=0.81)$. The study shows that recruitment of experienced employees by the firms, use of multi-skilled teams to execute their projects, recruitment and development of new graduates as well as participation in apprenticeship programmes enhance the sustainability of construction firms. Furthermore, enhancement of firm's technical capabilities, investment in research and development (R\&D) by construction firms, protection of firm's intellectual property, and participation in the development of industry standards and practices significantly improve sustainability of construction firms. This study also shows that actively monitoring international best practices, measuring how well the changes made by the firms have worked, and actively monitoring advances in related industries that might be applicable to construction firms contribute immensely to the sustainability of the firms. In addition, rewarding staff for maintaining networking linkages with strategically useful industry participants, pursuing partnering on projects, and maintaining long-term collaborative arrangements with other businesses greatly improve the sustainability of construction firms. This study is in tandem with the research conducted by Hassan, Shaukat, Nawaz and Naz (2013) who revealed that there are positive effects of innovation on firm performance.

Empirically, Table 3 shows that $66.1 \%$ of the variability in the overall sustainability of construction firms operating in the Niger Delta region of Nigeria is accounted for by the implementation of innovative practices by the construction firms. It also shows that $67.1 \%$ of the variability in the social sustainability of the firms is explained by the implementation of innovative practices by the construction firms. In the same manner, $83.8 \%$ of the variability in environmental sustainability of the construction firms is accounted for by the implementation of innovative practices by the firms, while $45.7 \%$ of the economic sustainability of the firms is accounted for by the level of implementation of innovative practices in the organisational processes by the construction firms.

Specifically, the study shows that $44.5 \%, 53.1 \%, 67.3 \%, 78.8 \%, 75.5 \%$, $77 \%, 72.9 \%$ and $78.6 \%$ of the variability in the employment level of the firms, infrastructural development, standard of living of the stakeholders, public and private sector investment, peace and security within the organisation, bio-diversity and eco-system stability, poverty reduction, and human health standard, respectively, are explained by the level of implementation of innovative practices by the top management teams of the construction companies. In addition, $37.8 \%$, $65 \%, 80.7 \%, 65.4 \%$ and $49.5 \%$ of the variability in effective communication of sustainability and other environmental management issues among contractors, suppliers and other professionals engaged by the construction firms, standardised management systems such as ISO 14001 or environmental management system in the organisation, implementation of environmental management programmes and the use of certified professionals, the inclusion of sustainability and other environmental management measures in tendering requirement, and the use of 
innovative features and renewable energy, respectively, are explained by the level of implementation of innovative practices by the top management teams of the construction companies. This study also demonstrates that the implementation of innovative practices by the construction firms accounts for $26.6 \%, 10.3 \%$ and $18.1 \%$ of the annual financial turnover, annual employment growth, and net income (profitability), respectively, of the construction firms operating in the Niger Delta region of Nigeria. This study is in agreement with the research conducted by Chan and Liu (2012) who posited that innovativeness influenced organisational productivity, profitability, competitiveness and sustainability at an organisation. This study is also in tandem with the research carried out by Gauthier and Wooldridge (2012) who revealed that innovations at the firm level helped address sustainability issues in the construction sector.

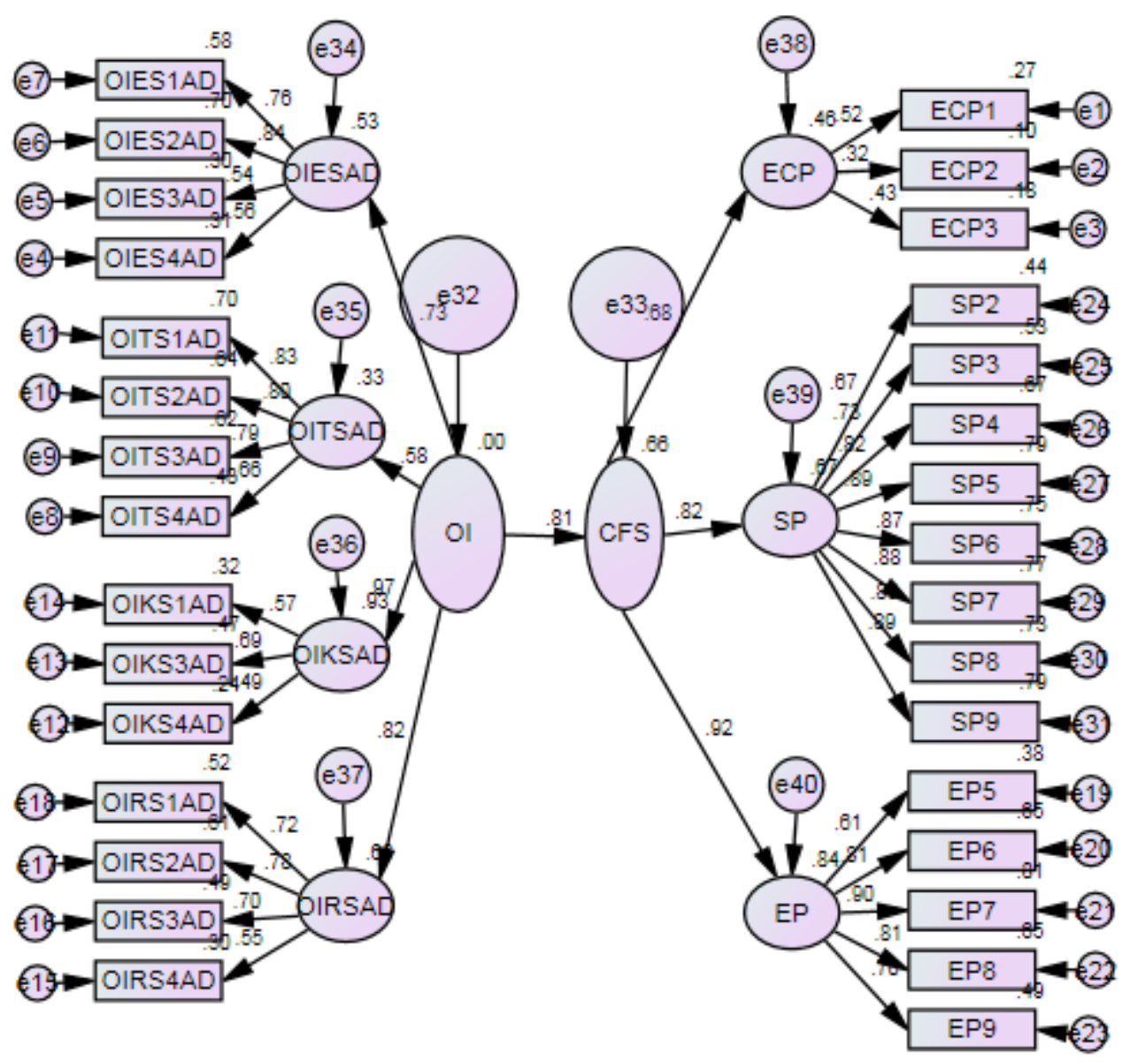

Fig. 3. Structural equation model for establishing the relationship between organisational innovativeness and sustainability of construction firms in Nigeria. 


\section{CONCLUSION}

This study has established an empirical relationship between organisational innovativeness and sustainability of construction firms using a structural equation modelling approach. The model estimation and modification, verification and validation have been carried out. The result of the model fit indices shows a satisfactory and good model fit. The correlation coefficient $(\beta=0.81)$ shows that organisational innovativeness positively influences the sustainability of construction firms. The study reveals that $66.1 \%$ of the variability in the overall sustainability of the construction firms operating in the Niger Delta region of Nigeria is accounted for by the implementation of innovative practices by the construction firms. It is concluded that $67.1 \%, 83.8 \%$ and $45.7 \%$ of the variability in the social, environmental and economic sustainability, respectively, are explained by the level of implementation of innovative practices by the top management teams of the construction firms. In line with the findings, this study concludes that the implementation of innovative practices at the firm level has a significant and positive influence on the overall sustainability of construction firms.

\section{REFERENCES}

Ali, H. A. E. M, Al-Sulaihi, I. A., and Al-Gahtani, K. S. (2013). Indicators for Measuring Performance of Building Construction Companies in Kingdom of Saudi Arabia. Journal of King Saud University - Engineering Sciences, 25(2), 125-134. https://doi.org/10.1016/j.jksues.2012.03.002

Bagozzi, R. P. and Yi, Y. (2012). Specification, Evaluation, and Interpretation of Structural Equation Models. Journal of the Academy of Marketing Science, 40, 8-34. https://doi.org/10.1007/s11747-011-0278-X

Bowen, F. E., Rostami, M., \& Steel, P. (2010). Timing is Everything: A Meta-analysis of the Relationships between Organisational Performance and Innovation. Journal of Business Research, 63(11), 1179-1185. https://doi.org/10.1016/j.jbusres.2009.10.014

Byrne, B. M. (2016). Structural Equation Modeling with AMOS. Basic Concepts, Applications and Programming, 3rd edition. Routledge.

Chan, I. Y., and Liu, A. M. (2012). Antecedents of Innovation Climate in Construction Firms in Hong Kong. International Journal of Construction Management, 12(4), 37-46. https://doi.org/10.1080/15623599.2012.10773199

Damanpour, F. (2010). An Integration of Research Findings of Effects of Firm Size and Market Competition on Product and Process Innovations. British Journal of Management, 21(4), 9961010. https://doi.org/10.1111/j.1467-8551.2009.00628.x

Doloi, H., Iyer, K. C., and Sawhney, A. (2011). Structural Equation Model for Assessing Impacts of Contractor's Performance on Project Success. International Journal of Project Management, 29(6), 687-695. https://doi.org/10.1016/j.ijproman.2010.05.007

Evangelista, R. and Vezzani, A. (2010). The Economic Impact of Technological and Management Innovations: A Firm-Level Analysis. Research Policy, 39(10), 1253-1263. https://doi.org/10.1016/j.respol.2010.08.004

Gauthier, J., and Wooldridge, B. (2012). Influences on Sustainable Innovation Adoption: Evidence from Leadership in Energy and Environmental Design. Business Strategy and the Environment, 21(2), 98-110. https://doi.org/10.1002/bse.716

Glick, W. H., Washburn, N. T., and Miller, C. C. (2005). The Myth of Firm Performance. Proceedings of the Annual Meeting of American Academy of Management. Honolulu, Hawaii.

Groves, R. M. (2006). Nonresponse Rates and Nonresponse Bias in Household Surveys. Public Opinion Quarterly, 70(5), 646-675. https://doi.org/10.1093/poq/nfl033 
Hair, J. F., Black, W. C., Babin, B. J., and Anderson, R. E. (2010). Multivariate Data Analysis: A Global Edition, $7^{\text {th }}$ Ed. Pearson Education.

Hassan, M. U., Shaukat, S., Nawaz, M. S., and Naz, S. (2013). Effects of Innovation Types on Firm Performance: An Empirical Study on Pakistan's Manufacturing Sector. Pakistan Journal of Commerce and Social Sciences, 7(2), 243-262.

Karabulut, A. T. (2015). Effect of Innovation Types on Performance of Manufacturing Firms in Turkey. Procedia-Social and Behavioural Sciences, 195, 1355-1364. https://doi.org/10.1016/j.sbspro.2015.06.322

Kazaz, A., Manisali, E., and Ulubeyli, S. (2008). Effect of Basic Motivational Factors on Construction Workforce Productivity in Turkey. Journal of Civil Engineering and Management, 14(2), 95-106. https://doi.org/10.3846/1392-3730.2008.14.4

Kline, R. B. (2004). Principles and Practice of Structural Equation Modelling (2nd ed.). The Guilford Press.

Lilja, R. (2009). Negotiated Environmental Agreements in Promoting Material Efficiency in industry - First Steps in Finland. Journal of Cleaner Production, 17(9), 863-872. https://doi.org/10.1016/j.jclepro.2009.01.002

Love, J. H. and Roper, S. (2015). SME Innovation, Exporting and Growth: A Review of Existing Evidence. International Small Business Journal, 33(1), 28-48. https://doi.org/10.1177/0266242614550190

Mafini, C. (2015). Predicting Organisational Performance Through Innovation, Quality And InterOrganisational Systems: A Public Sector Perspective. Journal of Applied Business Research, 31(3), 939-952. https://doi.org/10.19030/jabr.v31i3.9227

Molenaar, K., Washington, S., and Diekmann, J. (2000). Structural Equation Model of Construction Contract Dispute Potential. Journal of Construction Engineering and Management, 126(4), 268277. https://doi.org/10.1061/(ASCE)0733-9364(2000)126:4(268)

Moohammad, A. Y., Aini, Y. N., and Kamal, E. M. (2014). Influences of Firm Size, Age and Sector on Innovation Behaviour of Construction Consultancy Services Organizations in Developing Countries. Business Management Dynamics, 4(4), 01-09.

Rukundo, J. B. (2017). Firm Performance and Innovation in the Developing Countries: Evidence from Firm-Level Survey, Corporate Ownership \& Control, 15(1-1), 235-245. https://doi.org/10.22495/cocv15i1c1p7

Santos, J. B. and Brito, L. A. L. (2012). Toward a Subjective Measurement Model for Firm Performance. BAR, Braz. Adm. Rev. 9(no. Rio de Janeiro), 95-117. https://doi.org/10.1590/S1807-76922012000500007

Shen, L. Y., Tam, W. Y., Tam, L., and Ji, Y.-B. (2010). Project Feasibility Study: the key to Successful Implementation of Sustainable and Socially Responsible Construction Management Practice. Journal of Cleaner Production, 18(3), 254-259.

https://doi.org/10.1016/j.jclepro.2009.10.014

Schilling, M. A. (2013). Strategic Management of Technological Innovation. McGraw-Hill.

Shumacker, R. and Lomax, R. (2004). A Beginner's Guide to Structural Equation Modelling, 2nd edition, Lawrence Erlbaum associates.

Singh, R. K., Murty, H. R., Gupta, S. K and Dikshit, A. K. (2009). An Overview of Sustainability Assessment Methodologies. Ecological Indicators, 9(2), 189-212. https://doi.org/10.1016/j.ecolind.2008.05.011

Tabachnick, B. G. and Fidell, L. S. (2007). Using Multivariate Statistics (5th ed.). Allyn \& Bacon/Pearson Education.

Tam, W. Y. V. (2008). On the Effectiveness of Implementing a Waste-Management-Plan Method in Construction. Waste Management, 28(6), 1072-1080. https://doi.org/10.1016/j.wasman.2007.04.007

Walker, R. M., Damanpour, F., and Devece, C. A. (2011). Management Innovation and Organizational Performance: Mediating Role of Planning and Control. Journal of Public Administration Research and Theory, 21(2), 367-386. https://doi.org/10.1093/jopart/muq043 
Yusof, N., Kamal, E. M., Kong-Seng, L., and Iranmanesh, M. (2014). Are Innovations Being Created or Adopted in the Construction Industry? Business Administration and Business Economics, Economic Development, Strategic Management Organizational Theory \& Business Policy. SAGE. https://doi.org/10.1177/2158244014552424

Zulu, S. L. (2007). The Impact of Project Management Process Quality on Construction Project Performance: A Structural Equation Model. Unpublished PhD Thesis, Heriot Watt University, Edinburgh.

\section{AUTHORS' SHORT BIOGRAPHIES}

Dr Monday Otali is a Senior Lecturer at the Department of Building, Faculty of Environmental Studies, University of Uyo, Nigeria. Dr Monday Otali is a construction management expert. His research interests include sustainability in construction and construction management. He obtained his PhD degree in Construction Management in 2018 from the University of Uyo. He also obtained his Master degree (MSc in Construction Management) in 2011 from the University of Jos. Dr Monday Otali graduated with BSc (Hons) degree in Building from the Department of Building, University of Jos in 2006. Dr Monday Otali is a corporate member of the Nigerian Institute of Building (NIOB) and a registered and certified member of the Council of Registered Builders of Nigeria (CORBON). Dr Monday Otali won the J. Hausen Limited Prize for the Best MSc Project at the Department of Building, University of Jos in 2011.

E-mail: otalimonday@yahoo.com

Emmanuel Achuenu is a Professor of Construction Management at the Department of Building, Faculty of Environmental Sciences, University of Jos, Nigeria. He graduated with a degree in Building at the University of Jos in 1988. He obtained his MSc in Construction Management in 1993 and a PhD in Construction Management in 2000. He was the Head of the Department of Building at the University of Jos in 2009, and the Dean of the Faculty of Environmental Sciences in 2014. He has published articles in both international and local journals. He has also presented papers in both local and international conferences. He is a fellow of the Nigerian Institute of Building (NIOB). He won the following awards: National Universities Postgraduate Thesis Award Scheme: Winner, Best PhD Thesis (2001), Award Winner (2003): National Universities Commission Centrally Funded Research Scheme, National Universities Doctoral Thesis Award Scheme: Best Supervisor Award for supervising award winning Best $\mathrm{PhD}$ Thesis in Environmental Sciences among Nigerian Universities in 2009 category won by Dr O. F. Job conferred by NUC (2012), and National Universities Doctoral Thesis Award Scheme: Best Supervisor Award for supervising award winning Best PhD Thesis in Environmental Sciences among Nigerian Universities in 2012 category won by Dr Isaac Odesola conferred by NUC (2013).

E-mail: achuenue@unijos.edu.ng

Godwin Idoro is a Professor of Project Management at the Department of Building, Faculty of Environmental Sciences, University of Lagos, Nigeria. He obtained his PhD degree in Building in 2008 from the University of Lagos. He was the Head of the Department of Building, University of Lagos (2011-2015). He is a fellow of the Nigerian Institute of Quantity Surveying and a corporate member of the Nigerian Institute of Building. His current research focuses on project team integration in the construction industry in Nigeria. He has successfully supervised ten PhDs. He won the award of National Universities Doctoral Thesis Award Scheme: Best Supervisor Award for supervising award-winning Best $\mathrm{PhD}$ Thesis in Environmental Sciences among Nigerian Universities in 2012 category won by Dr Isaac Odesola conferred by NUC (2013).

E- mail: iroroidoro@yahoo.com 